\title{
MENINGKATAN HASIL BELAJAR SISWA PADA MATERI SIFAT-SIFAT BANGUN DATAR MELALUI PENDEKATAN EMBELAJARAN CONTEXTUAL TEACHING AND LEARNING (CTL) DI KELAS VB SDN 08 MANDONGA
}

\author{
Taslin $^{1, a)}$, La Ode Kaimuddin ${ }^{2}$ \\ ${ }^{1}$ Alumni Jurusan Pendidikan Guru Sekolah Dasar, FKIP Universitas Halu Oleo, \\ Jl. H.E.A. Mokodompit Kendari 93232, Indonesia \\ ${ }^{2}$ Dosen FKIP Universitas Halu Oleo, Jl. H.E.A. Mokodompit Kendari 93232, \\ Indonesia \\ a)e-mail: taslinabdullah@yahoo.com
}

\begin{abstract}
ABSTRAK
Penelitian ini bertujuan untuk meningkatkan hasil belajar siswa pada materi sifat-sifat bangun datar melalui pendekatan pembelajaran Contextual Teaching And Learning (CTL). Penelitian ini menerapkan desain penelitian tindakan kelas dengan subyek penelitian siswa kelas $\mathrm{V}^{\mathrm{B}}$ SD Negeri 08 Mandonga Kota Kendari. Dari hasil observasi, evaluasi dan refleksi pada setiap siklus dalam penelitian mengalami peningkatan. Tindakan siklus I hasil belajar siswa mencapai ketuntasan sebesar $43 \%$ dengan nilai rata-rata 63,1 pada siklus II mengalami peningkatan dengan ketuntasan sebesar $89 \%$ dengan nilai rata- rata 80 . Demikian halnya dengan keberhasilan aktivitas mengajar guru, pada siklus I pertemuan I sebesar 75\% meningkat pada pertemuan ke II sebesar 87,5\%.pada siklus II pertemuan I sebesar $93,75 \%$ meningkat sebesar $100 \%$ pada pertemuan II.Keberhasilan aktivitas belajar siswa siklus I pertemuan I sebesar $73,3 \%$ meningkat pada pertemuan II sebesar $77,0 \%$, pada siklus II pertemuan I sebesar $86,6 \%$ meningkat sebesar $94,1 \%$ pada pertemuan II.
\end{abstract}

Kata kunci: Hasil Belajar,Contextual Teaching and Learning dan Sifat-Sifat Bangun Datar

Improving Student Results At Creative Personality - Personality Build Flat Through Learning Approach Contextual Teaching And Learning (CTL) Elementary School Classroom 08 VB Mandonga Kendari

\begin{abstract}
This study aims to improve student learning outcomes in the material of flat-build properties through the Contextual Teaching And Learning (CTL) learning approach. This research applies a classroom action research design with research subjects of $V B$ grade students of SD Negeri 08 Mandonga Kendari City. From the results of observation, evaluation and reflection in each cycle in the study has increased. The action of the first cycle of student learning outcomes reached completeness by $43 \%$ with an average value of 63.1 in cycle II experienced an increase of $89 \%$ with an average value of 80 Likewise with the success of teacher teaching activities, in the first cycle the first meeting was $75 \%$ increased at the second meeting at $87.5 \%$. In the second cycle the first meeting was $93.75 \%$ increased by $100 \%$ at the second meeting. The success of student learning activities the first cycle of the first meeting was $73.3 \%$, increasing at the second meeting at $77.0 \%$, in the second cycle, the first meeting was $86.6 \%$, increasing by $94.1 \%$ at the second meeting.
\end{abstract}

Keyword: : Learning Outcomes, contextual teaching and learning and the properties of flat 
Matematika merupakan ilmu universal yang memberi perkembangan teknologi moderen,mempunyai peran penting dalam berbagai disiplin ilmu dan memajukan daya pikir manusia. Perkembangan pesat dibidang tekhnologi dan komunikasi sangat membutuhkan peran matematika. Hal ini memaksa manusia untuk mengusai berbagai disiplin ilmu. Diantaranya adalah mata pelajaran matematika. Oleh karena itu,mata pelajaran matematika perlu diberikan kepada semua peserta didik baik dari sekolah dasar sampai perguruan tinggi agar menjadi bekal bagi peserta didik sehingga mampu berpikir logis, analis, sistematis, kritis kreatif serta mampu bekerja sama. Kompetensi tersebut diperlukan agar peserta didik dapat memiliki kemampuan memperoleh, mengelolah dan memanfaatkan informasi untuk bertahan hidup pada keadaan yang dinamis, tidak pasti dan kompetitif (Aisyah, 2008:3)

Seiring dengan perkembangan yang terjadi, maka pembaharuan dibidang pendidikan mutlak harus dilaksanakan. Pemerintah telah melakukan berbagi macam upaya penyempurnaan baik yang menyangkut sistem maupun faktor eksternalnya. Diantara upaya pemerintah yang kini mulai terwujud adalah perubahan atau revisi kurikulum, penambahan fasilitas kegiatan pendidikan peningkatan kualitas pendidikan tenaga guru, penugasan belajar dan pengadaan media pembelajaran. Upaya ini diharapkan dapat membentuk manusia yang terampil, kreatif, inovatif dan profesional.

Sehubungan dengan hal tersebut maka upaya yang harus dilakukan adalah bagaimana mewujudkan proses kegiatan yang akan dilakukan oleh siswa agar terjadi perubahan yang akan dicapai sesuai dengan kompetensi yang diharapkan yang dimana hal ini bisa terjadi melalui kegitan pembelajaran.

Dalam kegiatan pembelajaran tersebut, guru harus berpedoman pada kurikulum Tingkat Satuan Pendidikan (KTSP). Dalam Undang-Undang Nomor 20 Tahun 2003 tentang Sistem Pendidikan Nasional menyebutkan bahwa kurikulum adalah seperangkat rencana dan pengaturan mengenai tujuan, isi, dan bahan pelajaran serta cara yang digunakan sebagai pedoman penyelenggaraan kegiatan pembelajaran untuk mencapai tujuan pendidikan tertentu (Permendikbud: 2013).
Berdasarkan pengertian tersebut, ada dua dimensi kurikulum, yang pertama adalah rencana dan pengaturan mengenai tujuan, isi, dan bahan pelajaran, sedangkan yang kedua adalah cara yang digunakan untuk kegiatan pembelajaran. Kurikulum yang digunakan di sekolah saat ini adalah Kurikulum Tingkat Satuan Pendidikan (KTSP). Salah satu mata pelajaran yang termuat dalam Kurikulum KTSP yaitu matematika yang disajikan dalam bentuk pembelajaran secara sentralistik yang mempunyai hubungan dengan kehidupan siswa sehari-hari.

Sejalan dengan salah satu tujuan pembelajaran matematika di Sekolah Dasar tercantum dalam Kurikulum Tingkat Satuan Pendidikan (KTSP) untuk mengembangkan potensi siswa menjadi kemampuan dalam berpikir reflektif bagi penyelesaian masalah sosial di masyarakat dan untuk membangun kehidupan masyarakat demokratis yang lebih baik. Dengan tujuan untuk mempersiapkan manusia Indonesia agar memiliki kemampuan hidup sebagai pribadi dan warga negara yang beriman, produktif, kreatif, inovatif, dan afektif serta mampu berkontribusi pada kehidupan bermasyarakat, berbangsa, bernegara, dan peradaban dunia (Permendikbud : 2013).

\section{Hasil Penelitian dan Pembahasan Hasil Penelitian}

Hasil observasi aktivitas mengajar guru dalam proses pembelajaran pada siklus I pertemuan I diketahui hanya 12 aktivitas dari 16 indikator yang dapat terlaksana dengan baik dengan presentase hanya mencapai $75 \%$ dan pada pertemuan ke II meningkat dengan 14 aktivitas dari 16 indikator yang terlaksana dengan baik dengan presentase $87,5 \%$.

Hasil observasi aktivitas belajar siswa dalam proses pembelajaran pada siklus I pertemuan pertama diketahui hanya 11 dari 15 indikator yang dapat terlaksana dengan baik dengan presentase hanya mencapai $73,33 \%$, pada pertemuan kedua meningkat dengan 13 dari 15 indikator yang terlaksana dengan baik dengan presentase mencapai $86,66 \%$. Hal ini disebabkan karena aktivitas siswa belum terbiasa dengan pendekatan pembelajaran Contextual Teaching And Learning $\quad$ (CTL) terkhusus dalam melakukan diskusi kelas hanya sebagian siswa saja yang terlibat

Jurnal Ilmiah Pembelajaran Sekolah Dasar Available online at:http://ojs.uho.ac.id/index.php/jipsd 
aktif.Selain itu, siswa juga belum berani dan percaya diri untuk menyampaikan ide atau gagasanya.

Hasil observasi mengajar guru siklus II pertemuan kedua meningkat dari pertemuan pertama.Dari 16 indikator atau kegiatan yang dilakukan semua terlaksana dengan baik dengan prentase mencapai $100 \%$.Untuk lebih jelasnya hasil obervasi aktivitas mengajar guru siklus I dan II pertemuan I dan II dapat dilihat pada lampiran 17 dan 22.

Dalam proses pelaksanakan tindakan telah menunjukan peningkatan yang memuaskan dan pelaksanaan aktivitas mengajar guru sudah cukup efektif dan telah mencapai indikator kinerja yang telah ditentukan yakni $80 \%$ skenario pembelajaran dapat terlaksana dengan baik .

Hasil obevasi aktivitas belajar siswa pada tindakan siklus II petemuan pertama, dari 15 aspek yang dinilai 14 aktivitas terlaksana dengan baik dengan presentase mencapai 93,33\%. Adapun 1 aspek yang belum terlaksana dengan baik, yaitu : Siswa tidak mendapatkan penghargaan atas hasil pekerjaan yang diperoh. Hasil observasi aktivitas belajar siswa pada siklus II pertemuan kedua, diketahui bahwa dari 15 indikator atau kegiatan yang harus dilaksanakan, 15 indikator terlaksana dengan baik dengan presentase sebesar $100 \%$.

Berdasarkan grafik di atas, aktivitas mengajar guru pada siklus I pertemuan I hanya mencapai $75 \%$ dan meningkat $87,5 \%$ pada pertemuan II. Pada siklus II perteman I mencapai $93,75 \%$ dan meningkat menjadi $100 \%$ pada pertemuan II.

Berdasarkan grafik diatas, hasil aktivitas belajar siswa mengalami peningkatan pada tiap siklus. Pada siklus I pertemuan I hanya mencapai $73,3 \%$ dan meningkat menjadi $77,0 \%$ pada pertemuan ke II. Pada siklus ke II terus mengalami peningkatan baik pada pertemuan pertama dengan perolehan sebesar $86,6 \%$ meningkat menjadi $94,1 \%$ pada pertemuan II.

Berdasarkan grafik diatas menunjukan adanya peningkatan hasil belajar siswa,yang diperoleh dari tes evaluasi pada tiap siklus. Hasil tes evaluasi yang di lakukan pada siklus I,diperoleh ketuntasan hasil belajar siswa secara klasikal (\%KBK) sebesar $43 \%$ atau sebanyak 16 dari 28 orang siswa dengan nilai rata-rata 63,1. Ketuntasan Belajar Klasikal (\% KBK) pada siklus II mengalami peningkatan yaitu mencapai $89 \%$ atau sebanyak 25 dari 28 orang siswa, dengan nilai rata-rata 80,8 . Hal ini menunjukan adanya peningkatan sebesar $46 \%$.

Hasil yang diperoleh siswa ini menunjukan bahwa penggunaan pendekatan pembelajaran Contextual Teaching and Learning dalam proses pembelajaran Matematika dapat lebih memotivasi siswa sehingga memberikan dampak positif terhadap pencapaian hasil belajar siswa. Indikator keberhasilan dalam penelitian sudah tercapai yaitu $80 \%$ siswa memperoleh nilai $\geq 70$, maka penelitian ini dihentikan pada siklus II.

Berdasarkan hal tersebut di atas, dapat dikatakan bahwa penggunaan pendekatan pembelajaran Contextual Teaching and Learning pada mata pelajaran Matematika pada pokok bahasan Sifat - sifat bangun datar siswa kelas $V^{\mathrm{B}}$ SD Negeri 08 Mandonga kota Kendari memberikan dampak yang lebih baik terhadap hasil belajar siswa.

\section{Simpulan}

Berdasarkan hasil analisis data tes hasil belajar siswa bahwa penggunaan pendekatan pembelajaran Contextual Teaching and Learning dalam proses pembelajaran dapat meningkatkan hasil belajar siswa pada materi sifat- sifat bangun datar kelas $V^{\mathrm{B}}$ SD Negeri 08 Mandonga Kota Kendari.Hal ini dapat dilihat dari perolehan nilai siswa setelah diadakan tes evaluasi yang meningkat dari siklus I dengan nilai ketuntasan ketuntasan hasil belajar siswa sebesar 57\% (12dari28 orang siswa) dengan nilai rata - rata 63 meningkat pada siklus II dengan nilai ketuntasan mencapai $89 \%$ (3dari28 orang siswa ) dengan nilai rata - rata 80.hal ini menunjukan adanya peningkatan hasil belajar siswa sebesar $46 \%$

Penggunaan pendekatan pembelajaran Contextual Teaching and Learning dapat meningkatkan aktivitas mengajar guru dalam proses pembelajaran . Hal ini dapat dilihat dari presentase Keberhasilan Aktivitas Mengajar Guru (KAMG) yang mengalami peningkatan dari siklus I pertemuan I sebesar $75 \%$ meningkat pada pertemuan II sebesar $87,5 \%$ .Pada siklus II juga mengalami peningkatan 
dari siklus I dengan perolehan 93,75\% pada pertemuan I meningkat sebesar $100 \% \%$ pada pertemuan II.

Penggunaan pendekatan pembelajaran Contextual Teaching and Learning juga dapat meningkat aktivitas belajar siswa dalam proses pembelajaran. Hal ini dapat diliahat dari presentase keberhasilan aktivitas belajar siswa ( KABS) mengalami peningkatan dari siklus I pertemuan I sebesar 73,3\% meningkat pada pertemuan II sebesar $77,0 \%$. Pada siklus II juga mengalami peningkatan dari siklus I dengan perolehan sebesar $86,6 \%$ pada pertemuan I dan meningkat sebesar $94,1 \%$ pada pertemuan II.

\section{DAFTAR PUSTAKA}

Fauzi,Ramdan.2012.Meningkatkan prestasi belajar matematika materi sifat-sifat bangun datar dengan pendekatan matematiak realistic kelas 5 SD negeri kaputran

IV Yogyakarta.skripsi.PGSD.FIP.Universit as Negeri Yogyakarta eprint.uny.ac.id08108244014:Yogyakar ta.

Firstianty ,Fenny \& Novel,Sasika.S. 2013.Cara Kilat Belajar Matematika SMP.Jakarta:

PT.Grasindo,Jln.Palmerah Barat.

Gerung, Nixon J. (kajian konseptual tentang belajar dan gaya belajar) http://journal.uniera.ac.id/pdf._reposito ry/juniera5zmiv716ep2zjivszhtg 1it0g.

Ihksani,Windi. 2013.meningkatkan hasil belajar siswa pada materi pokok organ pernapasan manusia melalui penerapan model pembelajaran kooperatif tipe team games tournament $(T G T)$ dikelas VB SD negeri 04 poasia kota kendari. Skripisi.Fkip.Universitas Haluoleo.

La iru \&Arihi, La Ode Safiun. 2012 . Analisis Penrapan Pendekatan,Metode Strategi Dan Model Model Pembelajaran.Bangun Tapan, Bantul.DIY.

Marwati. 2012. Meningkatkan Kemampuan Membaca Intensif Melalui Strategi
Ativitas Membaca Berpikir Terbimbing ( AMBT ) Siswa Kelas IV SD Negeri 8 Bonegunu Kabupaten Buton Utara.Skripisi.Fkip.Universitas Haluoleo.

Mayulu, Devy Yulianty S. 2013. Meningkatkan hasil Belajar Siswa Pada Materi Masalah Social Melalui Metode Inquiry di Kelas IV SDN 9 Telaga biru Kabupaten Gorontalo. Jurnal penelitian. PGSD FIP: Universitas Negeri Gorontalo

Muhsetyo,Gatot.dkk. 2009. Pembelajaran Matematika SD. Jakarta: Universitas Terbuka.

Nasution,Noehi \& Suryanto,Adi. 2007.Evaluasi

Pengajaran.Jakarta:Universitas Terbuka

Nete,Maya. 2012. Meningkatkan Hasil Belajar Matematika Siswa Kelas IV SDN 03 Kendari menggunakan Pendekatan Pembelajaran Contekstual Teaching And Learning(CTL) Dengan Pokok Bahasan Operasi Hitung Bilangan Bulat. Skripsi FKIP Universitas Haluoleo. Kendari.

Saminanto. 2010. Ayo Praktek, Penelitian Tindakan Kelas. Semarang: Perum Mijen Permai B.107.

Wardhani,IGAK \& Wihardit Kuswaya. 2010. Penelitian Tindakan Kelas. Jakarta: Universitas Terbuka

Wijaya ,Niken Ratna. 2013. Hubungan antara motivasi belajar dengan hasil belajar siswa pada materi pelajaran PKn di SMPN

77.http:.//skripsippknunj.com/wp-

content/uploads.Jurnal

Penelitian:Jakarta

Yunus, Muh. 2012. Meningkatkan Hasil Belajar Matematika Pada Materi Pecahan Dan Urutannya Dikelas IV SD Negeri Pombulaa Jaya Kecamatan 